\title{
1-3-1ラグビー競技者における頝椎のX線学的検討
}

\section{宮崎医科大学 整形外科}

○江夏剛（えなつ ごう）田島直也 作良彦 松元征徳 濱田浩朗 園田典生 田島卓也 <目的>ラグビー競技者における頝椎症性変化を単純X線にて評価しその特徵を検討する ことである。<対象>対象は某大学ラグビ一部員 22 名で平均年齢23歳 (19歳〜27 歳）、平均身長は $171 \mathrm{~cm}$ 、平均体重は $73 \mathrm{~kg}$ であった。ポジション別ではフォワード 12 名、バックス 10 名でラグビー歴は平均 2.8 年（0.5年〜 8.5年）であった。対照群として頸 椎症の既往のない健常男性25名（平均25歳）を用いた。<方法>単純X線側面像より頚 椎アライメントをBorden\&Rechtman法で計測し、各椎体、各椎間板レベルにおいて、 椎間板高、椎体扁平率、脊柱管前後径を測定し比較検討した。〈結果＞頝椎アライメント はラグビー部員平均 $4.9 \mathrm{~mm}$ 、対照群平均 $3.0 \mathrm{~mm}$ であった。ラグビー競技者では椎体扁平 率においてC6の低值が特徴的であった。

\section{1-3-2 スポーツ障害に対する装具療法（足底装具）}

乗松整形外科医院・長崎大学整形外科

○乗松敏晴（のりまつとしはる）, 乗松崇裕

【目的】スポーツが盛んになるにつれ、種々のスポーツ障害が発生している。障害が発生 した場合、スポーツの中止を指示されていることが多い。それらの選手に対して装具と適 切な指導により早期復帰をさせることが大切である。今回、比較的ハイレベルの選手を調 査し装具の目的を達していたかを調査することにする。

【対象と方法】症例はハイレベルにある 50 選手を対象とし、スポーツの種目、装具年龄、 整形外科的メティカルチェックの結果、復帰状況などを調査した。

【結果】選手は男性 40 人、女性 10 人でスポーツは、陸上、サッカー、ラグビーなど 1 0 種目に渡っていた。装具装着年齢は、平均 17 . 4 歳であり、装着期間は、バラツキが あった。スポーツには全員復帰し、オリンピック選手、Jリーガーなどとして活躍してい た。メディカルチェックと適合判定が重要である。 


\section{1-3-3バスケットボール選手の下肢スポーツ外傷 及び障害}

野崎東病院整形外科、*同病院リハビリテーション部 ○花田弘文(はなだひろふみ)、後藤三晴、*尾崎勝博

【目的】近年、スポーツ人口の増加、スポーツの多様化に伴い、スポーツ外傷・障害患者は 增加している。特に、バスケットボールは多彩なスピードを要し、接触プレーを有するため、 ACL、ATFLを中心とした下肢外傷・障害が多い。我々は、バスケットボール選手の下肢外 傷・障害に関与する様々な因子、及び対応策について報告する。

【対象および方法】全国大会連続出場している高校および県下の有名高校のバスケット部員 の約160名にアンケート及び現地調査を行ない、受傷要因及び対応策を検討した。

【まとめほとんどの選手でバスケットボールのハイカットシューズはATFL予防効果に有 効だった。ハイカットシューズによる膝関節へおよほす影響は不明であった。また、下肢外 傷・障害を生じた選手のほとんどが床の滑りやすさを指摘していた。スポーツ医は安定性の あるシューズ、正しいフットワークの指導をおこなうべきである。

\section{1-3-4 野球による股関節覀脱臼骨折の 1 例}

\section{川鴪整形外科病院}

○村上太三（むらかみたいぞう）、佐々木誠人、川嶌眞人、

強大な外力によって生じる外傷性股関節脱臼は、スポーツ外傷としては稀なものである。 今回、我々は野球にて後方飛球を追い背走中転倒し、股関節亜脱臼し寛骨臼骨折を生した 症例を経験したので報告する。

（症例） 25 歳男性。（主訴）右股関節痛による歩行困難。(現病歴) 野球で背走中転倒し 歩行困難亡なる。(現症) 初診時、右下肢は伸展位。ROM は疼痛により制限。(レントゲ ン所見）右股関節脱臼はなく、大きな単一骨片を主とした寛骨臼骨折があった。MRIを施 行、骨片は寛骨臼後方にあった。骨片はKワイヤーで固定 ( 6 週抜釘)、4 週免荷の後 1 2 週で独歩、現在受傷 4 ヶ月特に問題ない。本症例は、non-contact injaryにもかかわらず 寛骨臼骨折を伴う股関節要脱臼を生じた。受傷起点を主に文献的考察を行った。 